\title{
Effects of Nitrogen and Calcium Carbonate on Growth, Rosmarinic Acid Content and Yield of Satureja hortensis L.
}

\author{
Mesbah Babalar (Corresponding author) \\ Department of Horticultural Science, University of Tehran, Karaj, Iran \\ Tel: 98-912-169-8263Ｅ-mail: mbabalar@ut.ac.ir \\ Hasan Mumivand \\ Department of Horticultural Science, University of Tehran, Karaj, Iran \\ Javad Hadian \\ Medicinal Plants and Drug Research Institute, Shahid Beheshti University \\ G. C., Evin, Tehran, Iran \\ Seyed Mohamad Fakhr Tabatabaei \\ Department of Horticultural Science, University of Tehran, Karaj, Iran
}

\begin{abstract}
Because of the presence of free phenolic acids, especially rosmarinic acid, extracts of Satureja hortensis L. possess antioxidant and antimicrobial activity. The production of rosmarinic acid by plant cells can be modified by many factors. In the present study, the changes induced by calcium carbonate and nitrogen application on rosmarinic acid content, plant growth, and yield of S. hortensis cv. Saturn were investigated. Nitrogen fertilization significantly increased plant height, fresh and dry weights of herb as well as rosmarinic acid content and yield. $\mathrm{CaCO}_{3}$ treatments did not affect rosmarinic acid content or yield, while the fresh and dry weights of herb were increased by applying $5 \mathrm{tha}^{-1} \mathrm{CaCO}_{3}$.
\end{abstract}

Keywords: Satureja hortensis, Rosmarinic acid, Nitrogen, Calcium carbonate

\section{Introduction}

Satureja hortensis L. (family Lamiaceae and subfamily Nepetoideae) is a well-known medicinal and spice plant cultivated in several areas of the world (Hadian et al., 2008). The aerial parts of this plant are frequently used as tea or additive in commercial spice mixtures for many foods to offer aroma and flavor (Sahin et al., 2003). S. hortensis has also been used as folk remedy to treat various ailments such as cramps, muscle pains, nausea, indigestion, diarrhea and infectious diseases (Zargari, 1970; Sahin et al., 2003).

The extracts of $S$. hortensis contain flavonoids and caffeic acid derivatives among them rosmarinic acid is present in higher concentration and it is mainly responsible for biological activity of the extracts (Madsen et al., 1996). Rosmarinic acid (RA) is an ester of caffeic acid and 3,4 dihydroxyphenyllactic acid. It is commonly found in species of the Boraginaceae and the subfamily Nepetoideae of the Lamiaceae (Petersen and Simmonds, 2003). RA possesses a multitude of biological activities, e.g. antiviral, antibacterial, anti-inflammatory and antioxidant, which makes it a valuable product for the pharmaceutical and cosmetic industries (Li et al., 2005). The presence of RA in medicinal plants, herbs and spices has beneficial and health promoting effects. In plants, RA is supposed to act as a performed constitutively accumulated defense compound (Petersen and Simmonds, 2003).

It is a common understanding that secondary metabolites production of medicinal plants is influenced by the genetics and cultivation conditions such as climate, plant density and use of fertilizers (Baranauskiene et al., 2003). Nitrogen is one of the most important nutrients for crop production and influences both the amount and quality of plant secondary metabolites (Sifola and Barbieri, 2006). Also, plants need calcium to continue normal function of their membranes, to growth of the meristematic tissues and the youngest leaves and to send signals in response to internal and external cues (Dordas, 2009). The effects of nitrogen fertilizer on growth and secondary 
metabolites content and yield of different plants have been shown in many studies (Ayanoglu et al., 2002; Ashraf et al., 2005; Sifola and Barbieri, 2006; Ozguven et al., 2008; and Strissel et al., 2005). On the other hand, many researchers have studied the effects of $\mathrm{Ca}$ on plant growth and production of secondary metabolites of several medicinal plants (Lee and Yang, 2005; Supanjani et al., 2005; Karaivazoglu et al., 2007; and Dordas, 2009).

There is no information available in the literature on the calcium and nitrogen effects on the RA production of $S$. hortensis. Thus, the present study aimed to investigate the influences of nitrogen and calcium carbonate application rates on plant growth, rosmarinic acid content and yield of $S$. hortensis cv. Saturn.

\section{Materials and Methods}

\subsection{Field experiment}

A field experiment was conducted in 2008 at the experimental garden of the Research Center of Horticultural Sciences Department, University of Tehran, Karaj, Iran (altitude $1320 \mathrm{~m}$, longitude $51^{\circ} \mathrm{E}$, latitude $35^{\circ} 48^{\circ} \mathrm{N}$ ). The average day and night temperatures during experiment were 26.9 and $20.7^{\circ} \mathrm{C}$, respectively. At the beginning of the study, some physico-chemical characteristics of the soil at the depth of $30 \mathrm{~cm}$ were analyzed (Table 1). The seeds of $S$. hortensis cv. Saturn, a bred cultivar with high rosmarinic acid content, were sown in the greenhouse on July 5, 2008 in small pots containing sand, clay and humus (1:1:1). After four weeks, the plantlets with 7-10 $\mathrm{cm}$ height were transplanted to the field at a density of 6.35 plants $\mathrm{m}^{-2}(0.45 \times 0.35 \mathrm{~m}$ distance $)$. The length and width of each plot were 2.1 and $1.8 \mathrm{~m}$, respectively (total area $=3.78 \mathrm{~m}^{2}$ ). A factorial experiment based on the randomized complete block design with three replications was used. $\mathrm{N}$ fertilizer was applied at different levels of 0 (unfertilized), 50, 100 and $150 \mathrm{Kg} \mathrm{N}$ ha ${ }^{-1}$, as $\mathrm{NH}_{4}\left(\mathrm{NO}_{3}\right)$. These fertilizers were divided into two equal doses and added at first and fifth weeks after transplanting. A few months prior to transplanting, $\mathrm{CaCO}_{3}$ treatment was carried out as slaked lime at different levels of 0 (control), 5 and $10 \mathrm{t} \mathrm{ha}^{-1}$ by mixing properly with soil (up to 30 $\mathrm{cm}$ depth). During the growing period, the plants were weekly irrigated and kept free of weeds by hand hoeing.

\subsection{Sampling and traits analysis}

Eight plants were sampled from the inner part of each plot on October $12^{\text {th }}$ ( 71 days after transplanting) at full bloom. Plant height and fresh weight of the herb were measured for each sample. Plants were then dried in the shade and dry weight was recorded.

\subsection{Preparation of crude extract}

The aerial parts of plants were grounded to fine powder out of which $400 \mathrm{mg}$ was suspend in $10 \mathrm{ml}$ of $\mathrm{MeOH}$ and mixed vigorously. Extraction was performed by sonicating the sample for $30 \mathrm{~min}$ (Power Sonic 450, Hwashing, Korea). The extract was then filtered, and stored at $4^{\circ} \mathrm{C}$ until analysis.

\subsection{Chromatographic condition}

\subsubsection{Instrumentation}

Camag TLC (Thin Layer Chromatography) system composed of Camag linomat 5 autosampler, TLC scanner 3, and Wincats 1.2.2 software (CAMAG, Muttenz, Switzerland) was used. Samples applied in 6-mm length at 10 $\mathrm{mm}$ intervals under $\mathrm{N}_{2}$ stream. The experiment was performed on TLC aluminum sheets silica gel $60 \mathrm{~F} 254$ plates $(10 \times 10 \mathrm{~cm})$, which was developed to a distance of $85 \mathrm{~mm}$ in a CAMAG ${ }^{\circledR}$ twin trough chamber previously equilibrated with the mobile phase: acetone-toluene-formic acid (4:5:1) for RA. The developed TLC plate was dried using a hair dryer for 5 min with cool air. Position of the first track was $15 \mathrm{~mm}$. Vertical development to a distance of $85 \mathrm{~mm}$ was performed on $10 \times 10 \mathrm{~cm}$ CAMAG Twin Trough Chamber. Quantitative evolution of the plate was performed in absorption-reflection mode at $329 \mathrm{~nm}$ for RA, slit width of $6 \times 0.45 \mathrm{~mm}$ and data resolution $100 \mu \mathrm{m}$ step and scanning speed $20 \mathrm{~mm}$. Quantification of RA in the extract of S. hortensis was performed by external standard method, using pure compound. RA appeared as brightly yellow spot at $\mathrm{Rf} \sim 0.42$.

\subsubsection{Calibration curve for rosmarinic acid}

Stock solutions of RA $\left(100 \mu \mathrm{g} \mathrm{mL}^{-1}\right)$ were prepared in methanol and different amounts (50 to $1000 \mathrm{ng}$ spot-1 for RA) were applied on a TLC plate, using Linomat $V$ for preparing six point calibration graph of peak area versus concentration.

\subsection{Data analysis}

Data of all measured parameters were subjected to variance analysis using MSTAT-C statistical software. When the analysis of variance showed significant treatment effects, Duncan's multiple range test was used to compare treatment means at a probability level of 0.05 . 


\section{Results}

\subsection{Growth and yield parameters}

Results of the study showed that nitrogen fertilization up $100 \mathrm{Kg} \mathrm{ha}^{-1}$ significantly increased plant height of $S$. hortensis $\left(37.64 \pm 0.66 \mathrm{~cm}\right.$ ), but at $150 \mathrm{Kg} \mathrm{ha}^{-1}$ it was slightly decreased, but statistically not significant (Fig 1). On the other hand, the effect of $\mathrm{CaCO}_{3}$ treatments on the plant height was not significant.

Nitrogen fertilization significantly affected fresh weight of herb as well as dry weight. Fresh weight was greater in the plants fertilized with $100 \mathrm{Kg} \mathrm{ha}^{-1}\left(198.0 \pm 6.8 \mathrm{~g} \mathrm{plant}^{-1}\right)$ than the control $\left(171.1 \pm 6.4 \mathrm{~g} \mathrm{plant}^{-1}\right)$, while no further increase was observed in plots fertilized with $150 \mathrm{Kg} \mathrm{ha}^{-1}$ (Fig. 2). Dry weight was also significantly increased by nitrogen fertilization as it was highest $\left(48.53 \pm 1.63 \mathrm{~g} \mathrm{plant}^{-1}\right)$ at $150 \mathrm{~kg} \mathrm{ha}^{-1}$ (Fig. 3). There was a significant effect of $\mathrm{CaCO}_{3}$ treatment on fresh and dry weights of the herb. The highest plant fresh and dry weights $\left(200.2 \pm 6.4\right.$ and $46.7 \pm 1.7$ g plant $^{-1}$, respectively) was obtained from adding $5 \mathrm{t} \mathrm{ha}^{-1} \mathrm{CaCO}_{3}$ (Fig's. 4 \& 5). Furthermore, the interaction between $\mathrm{CaCO}_{3}$ and $\mathrm{N}$ treatments was not significant for any trait.

\subsection{Rosmarinic acid content and yield}

TLC analysis of RA content of $S$. hortensis methanolic extract showed that nitrogen fertilization had a significant effect on RA content. The highest RA content $\left(1.15 \pm 0.07 \mathrm{mg} \mathrm{g}^{-2} \mathrm{DW}\right)$ was obtained from the treatment of 150 $\mathrm{kg} \mathrm{ha}^{-1}$ (Fig. 6). Rosmarinic acid yield was also significantly increased by nitrogen fertilization and it was highest $\left(352 \pm 19.7 \mathrm{mg} \mathrm{m}^{-2}\right)$ at $150 \mathrm{~kg} \mathrm{ha}^{-1}$ (Fig. 7). But $\mathrm{CaCO}_{3}$ application had no effect on RA content and yield of methanolic extract. Interaction between nitrogen and $\mathrm{CaCO}_{3}$ application was not significant for both RA content and yield.

\section{Discussion}

As was mentioned above, plant height and fresh and dry weights of herb were significantly increased by nitrogen fertilization up to $100 \mathrm{~kg} \mathrm{ha}^{-1}$, while no further increase was observed in plots fertilized with $150 \mathrm{Kg} \mathrm{ha}^{-1}$. This agreed with the results of Ram et al. (1995), Ayanoglu et al. (2002), Baranauskiene et al. (2003) and Ashraf et al. (2005). Up to $75 \%$ of leaf $\mathrm{N}$ content is found in chloroplasts mainly as a part of riboluse bisphosphate carboxylase (Rubisco) (Dordas and Sioulas, 2008). When there was adequate N supply in the soil, photosynthesis rate increase and enabled the plant to grow rapidly and produce considerable biomass. In addition, the application of nitrogen fertilizer increased the uptake and accumulation of other nutrients such as phosphorus (P) and potassium (K) (Baranauskiene et al., 2003). Hence, nitrogen plays an important role in vegetative growth and basic metabolism of plant, which might be directly or indirectly involved in production of secondary metabolites (Baricevic and Zupancic, 2002). Under nitrogen deficiency, due to the reduction of chlorophyll content and Rubisco activity, growth and development is inhibited and plant yield decrease (Dordas and Sioulas, 2008). High nitrogen fertilization may also causes a decrease in activities of phosphoenolpyrovate carboxylase (PEP) and Rubisco thereby reducing the photosynthesis rate, plant growth and accumulation of secondary products (Ashraf et al., 2006), although in the present study no decrease in plant growth was observed with high nitrogen fertilization $\left(150 \mathrm{~kg} \mathrm{ha}^{-1}\right)$. Moreover, nitrogen fertilization significantly increased RA content and yield of extract. It is well known that biosynthesis of RA starts with the amino acids L-phenylalanine and L-tyrosine. Also, eight enzymes are involved in the RA biosynthesis (Petersen and Simmonds, 2003). Since N is present in the structure of amino acids and enzymes, therefore increase in RA content by nitrogen fertilization could be explained by the increase in biosynthesis of RA precursors (L-phenylalanine and L-tyrosine) and catalyzor enzymes. Coronado et al. (1995) reported that root flavonoid and isoflavonoid production of Medicago sativa L. increased under nitrogen limiting conditions due to the enhancement of expression of the flavonoid biosynthesis genes. Ozguven et al. (2008) showed that nitrogen fertilizer had a significant effect on artemisinin content of Artemisia annua and maximum of artemisinin was obtained at $80 \mathrm{~kg} \mathrm{ha}^{-1}$. Also, the increase in RA yield by enhanced level of nitrogen depends on an increase in both plant biomass and RA content.

Concerning the effect of $\mathrm{CaCO}_{3}$ application, plant growth and performance were increased with the application of $\mathrm{CaCO}_{3}$ up to $5 \mathrm{t} \mathrm{ha}^{-1}$, while further increase in $\mathrm{CaCO}_{3}$ reduced the growth. Similar result was reported by Supanjani et al. (2005), who mentioned that plant growth and yield of Chrysanthemum coronarium L. was increased by applying of $\mathrm{CaCO}_{3}$ up to $2 \mathrm{t} \mathrm{ha}^{-1}$ and more amounts decreased yield. Also Lee and Yang (2005) reported that an increase in plant growth and yield of $C h$. boreale $\mathrm{M}$. was observed with increasing $\mathrm{CaCO}_{3}$ levels up to $1.5 \mathrm{t} \mathrm{ha}^{-1}$. Since $S$. hortensis L. is characterized as calcicole species and in natural habitats it is mainly found in calcareous soils (Ghahraman, 1996), this plant responded to higher levels of soil $\mathrm{CaCO}_{3}$ content more positively than other species. Moreover, Quaggio et al. (2004) mentioned that the effect of $\mathrm{CaCO}_{3}$ treatment on peanut yield depends on many factors including the initial $\mathrm{Ca}$ and Mo status of the soil, time of $\mathrm{CaCO}_{3}$ application and the peanut cultivar. The increase in plant growth and yield at $5 \mathrm{tha}^{-1} \mathrm{CaCO}_{3}$ could be explained 
by several reasons including enhancement of exchangeable $\mathrm{Ca}$ and $\mathrm{Mg}$, increase of available Mo, decrease of $\mathrm{Al}$, $\mathrm{Mn}$ and heavy metals toxicity due to increase of $\mathrm{pH}$ and improvement of soil characteristics (increase of pore volume and optimum moisture content) (Quaggio et al., 2004; Bakker et al., 2005; Rajasekaran, 2005). It seems that the decrease in growth by application of $10 \mathrm{t} \mathrm{ha}^{-1} \mathrm{CaCO}_{3}$ could be related to excessive Ca content of soil solution, which causes precipitation of P, S and Zn (Wenming, 2001; Bakker et al., 2005; Rajasekaran, 2005). Although the effect of $\mathrm{CaCO}_{3}$ on other secondary metabolites has been shown in several studies (Lee and Yang, 2005 and Supanjani et al., 2005), RA content and yield were not significantly affected by $\mathrm{CaCO}_{3}$ treatment in the present study.

\section{Conclusion}

From the above-mentioned results, it could be concluded that nitrogen fertilizer has significant effect, not only on plant growth, but also on RA production. Since the commercial value of $S$. hortensis depends on the amount of phenolic acids mainly RA, the increase in RA yield induced by $\mathrm{N}$ fertilization has positive effects. Furthermore, $\mathrm{CaCO}_{3}$ application significantly increased plant growth, but had no significant effect on RA production of $S$. hortensis. Finally, application of $150 \mathrm{~kg} \mathrm{~N} \mathrm{ha}^{-1}$ without $\mathrm{CaCO}_{3}$ was identified as the best treatment for the production of RA.

\section{References}

Ashraf, M., Ali, Q., \& Iqbal, Z. (2006). Effect of nitrogen application rate on the content and composition of oil, essential oil and minerals in black cumin (Nigella sativa L.) seeds. J. Sci. Food Agric., 86, 871-876.

Ashraf, M., Ali, Q., \& Rha, E.S. (2005). The effect of applied nitrogen on the growth and nutrient concentration of Kalonji (Nigella sativa). Aust. J. Exp. Agric., 45, 459-463.

Ayanoglu, F., Mert, A., \& Kirici, S. (2002). The effects of different nitrogen doses on Artemisia annua L. J. Herbs Spi. Med. Plants, 9, 399-404.

Bakker, C., Rodenburg, J., \& Bodegom, P. (2005). Effects of Ca- and Fe-rich seepage on P availability and plant performance in calcareous dune soils. Plant Soil, 275, 111-122.

Baranauskiene, R., Venskutonis, P.R., Viskelis, P., \& Dambrauskiene, E. (2003). Influence of nitrogen fertilizers on the Yield and Composition of Thyme (Thymus vulgaris). J. Agric. Food Chem., 51, 7751-7758.

Baricevic, D., \& Zupancic, A. (2002). The impact of drought stress and/or nitrogen fertilization in some medicinal plants. J. Herbs Spi. Med. Plants, 9, 53-64.

Coronado, C., Zuanazzi, J.A.S., Sallaud, C., Quirion, J.C., Esnault, R., Husson, H.P., Kondorosi, A., \& Ratet, P. (1995). Alfalfa Root Flavonoid Production Is Nitrogen Regulated. Plant Physiol., 108, 533-542.

Dordas, C. (2009). Foliar application of calcium and magnesium improves growth, yield, and essential oil yield of oregano (Origanum vulgare ssp. hirtum). Ind. Crop. Prod., 29, 599-608.

Dordas, C.A., \& Sioulas, C. (2008). Safflower yield, chlorophyll content, photosynthesis, and water use efficiency response to nitrogen fertilization under rain fed conditions. Ind. Crop. Prod., 27, 75-85.

Ghahraman A. (1996). Color Atlas of Iranian Flora (In Persian). Research Institute of Forests and Rangelands Publishing.

Hadian, J., Tabatabaei, S.M.F., Naghavi, M.R., Jamzad, Z., \& Ramak-Masoumi, T. (2008). Genetic diversity of Iranian accessions of Satureja hortensis L. based on horticultural traits and RAPD markers. Sci. Hortic., 115, 196-202.

Karaivazoglou, N.A., Tsotsolis, N.C., \& Tsadilas C.D. (2007). Influence of liming and form of nitrogen fertilizer on nutrient uptake, growth, yield, and quality of Virginia (flue-cured) tobacco. Field Crop. Res., 100, 52-60.

Lee, K.D., \& Yang, M.S. (2005). Changes in mineral and terpene concentration following calcium fertilization of Chrysanthemum boreale M. Res. J. Agric. Biol. Sci., 1, 222-226.

Li, W., Koike, K., Asada, Y., Yoshikawa, T., \& Nikaido, T. (2005). Rosmarinic acid production by Coleus forskohlii hairy root cultures. Plant Cell Tiss. Org., 80, 151-155.

Madsen, H.L., Andersen, L., Christiansen, L., Brockhoff, P., \& Bertelsen, G. (1996). Antioxidative activity of summer savory (Satureja hortensis L.) and rosemary (Rosmarinus officinalis L.) in minced, cooked pork meat. Food Res. Tech., 203, 333-338.

Ozguven, M., Sener, B., Orhan, I., Sekeroglu, N., Kirpik, M., Kartal, M., Pesin, I., \& Kaya, Z. (2008). Effects of varying nitrogen doses on yield, yield components and artemisinin content of Artemisia annua L. Ind. Crop. Prod., 27, 60-64. 
Petersen, M., \& Simmonds, M.S.J. (2003). Molecules of Interest - Rosmarinic acid. Phytochemistry, 62, 121-125.

Quaggio, J.A., Gallo, P.B., Owino-Gerroh, C., Abreu, M.F., \& Cantarella, H. (2004). Peanut response to lime and molybdenum application in low pH soils. Rev. Bras. Cienc. Solo., 28, 659-664.

Rajasekaran, G. (2005). Sulphate attack and ettringite formation in the lime and cement stabilized marine clays. Ocean Eng., 32, 1133-1159.

Ram, M., Ram, D., \& Singh, S. (1995). Irrigation and nitrogen requirements of Bergamot mint on a sandy loam soil under sub-tropical conditions. Agric. Water Manage., 27, 45-54.

Sahin, F., Karaman, I., Gulluce, M., Oguteu, H., Sengul, M., Adıguzel, A., Ozturk, S., \& Kotan, R. (2003). Evaluation of antimicrobial activities of Satureja hortensis L. J. Ethnopharmacol., 87, 61-65.

Sifola, M.I., \& Barbieri, G. (2006). Growth, yield and essential oil content of three cultivars of basil grown under different levels of nitrogen in the field. Sci. Hortic., 108, 408-413.

Strissel, T., Halbwirth, H., Hoyer, U., Zistler, C., Stich, K., \& Treutter, D. (2005). Growth-Promoting Nitrogen Nutrition Affects Flavonoid Biosynthesis in Young Apple (Malus domestica Borkh.) Leaves. Plant Biol., 7, 677-685.

Supanjani, Tawaha, A.R.M., Yang, M.S., Han, H.S., \& Lee, K.D. (2005). Role of calcium in yield and medicinal quality of Chrysanthemum Coronarium L. J. Agron., 4, 186-190.

Wenming, D., Zhijun, G., Jinzhou, D., Liying, Z., \& Zuyi, T. (2001). Sorption characteristics of zinc(II) by calcareous soil radiotracer study. Appl. Radiat. Isot., 54, 371-375.

Zargari, A. (1970). Medicinal Plants (In Persian), vol. 4. Tehran University, pp. 42-4.

Table 1. Some physico-chemical properties of the soil of experimental field

\begin{tabular}{ll}
\hline Soil property & content \\
\hline Total N $(\%)$ & 0.09 \\
Available K (ppm) & 696 \\
Available P (ppm) & 104 \\
$\mathrm{Ca}\left(\right.$ meq lit $\left.{ }^{-1}\right)$ & 20 \\
$\mathrm{pH}$ & 6.4 \\
$\mathrm{EC}\left(\mathrm{ds} \mathrm{m}^{-1}\right)$ & 1.26 \\
Organic C $(\%)$ & 0.93 \\
Organic matter $\left(\mathrm{g} \mathrm{Kg}^{-1}\right)$ & 6.25 \\
Textural class & Clay loamy \\
Active lime $(\%)$ & 5.1 \\
\hline
\end{tabular}

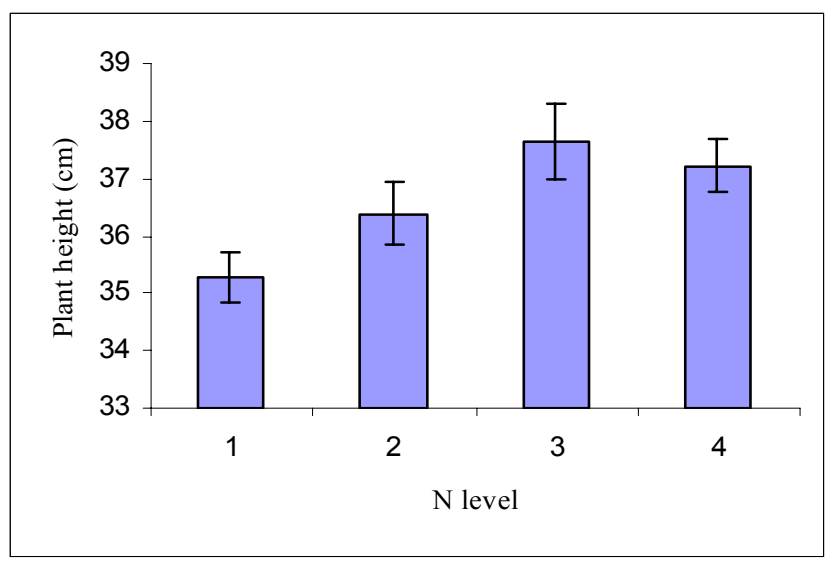

Figure 1. The effect of N fertilizer levels on plant height of S. hortensis cv. Saturn 


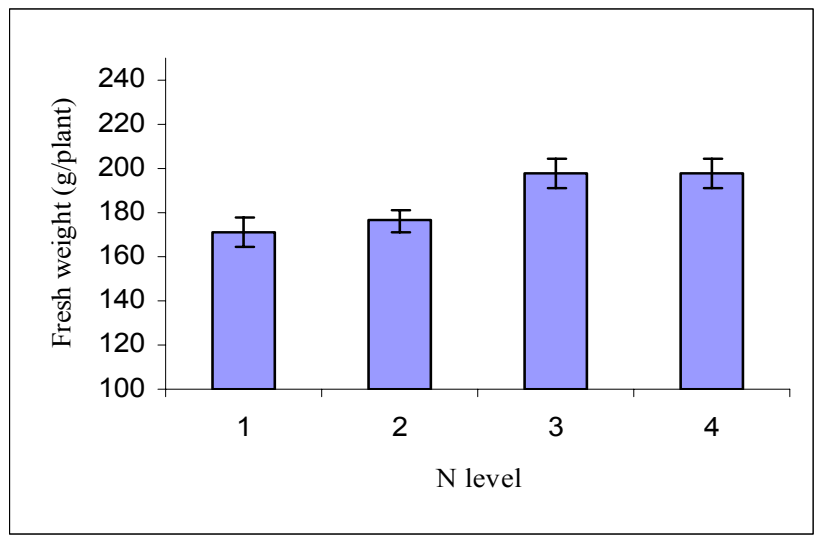

Figure 2. The effect of $\mathrm{N}$ fertilizer levels on fresh weight of $S$. hortensis cv. Saturn

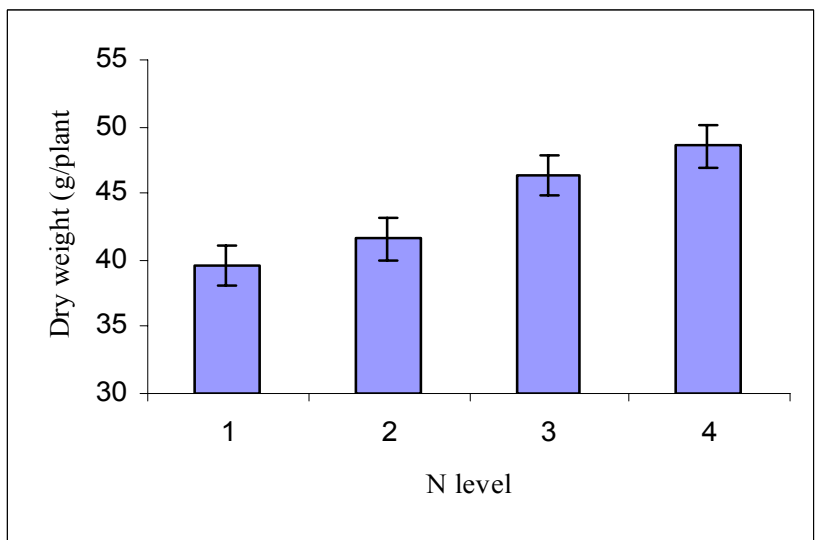

Figure 3. The effect of $\mathrm{N}$ fertilizer levels on dry weight of $S$. hortensis cv. Saturn

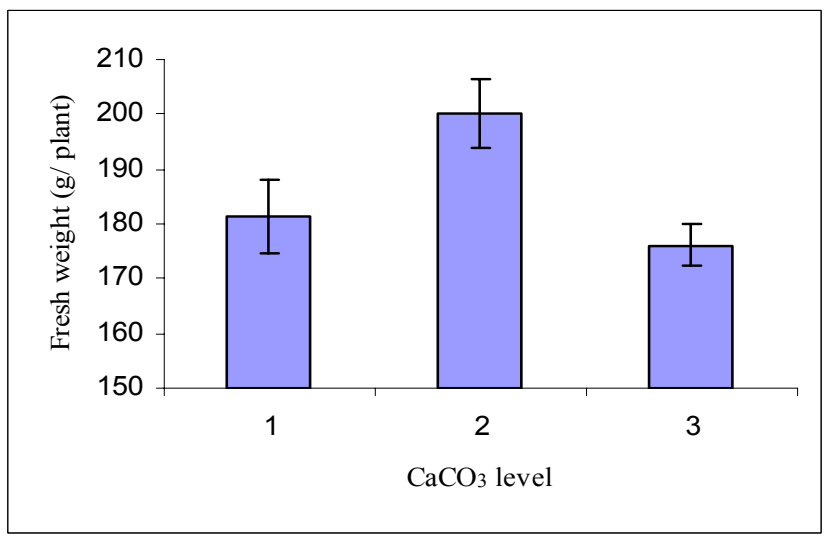

Figure 4. The effect of $\mathrm{CaCO}_{3}$ levels on fresh weight of $S$. hortensis cv. Saturn 


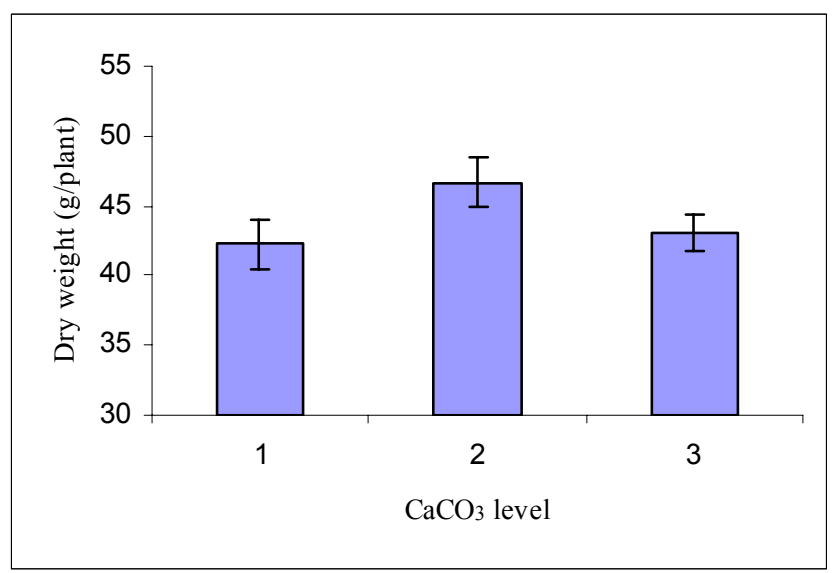

Figure 5. The effect of $\mathrm{CaCO}_{3}$ levels on dry weight of $S$. hortensis cv. Saturn

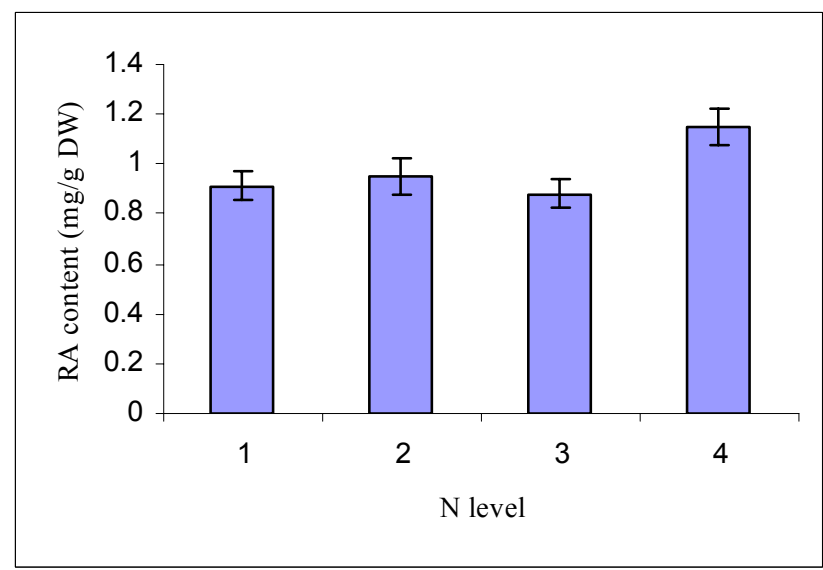

Figure 6. The effect of $\mathrm{N}$ fertilizer levels on RA content of methanolic extract of S. hortensis cv. Saturn

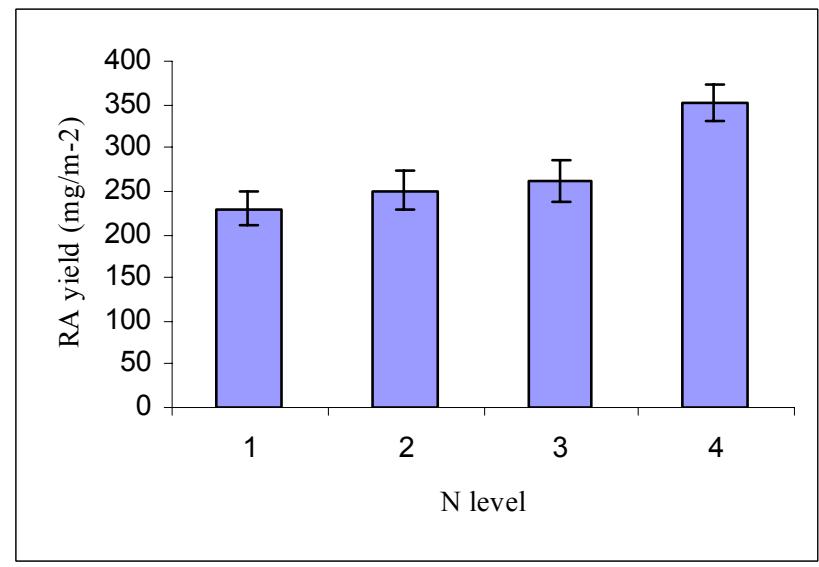

Figure 7. The effect of N fertilizer levels on RA yield of S. hortensis cv. Saturn 